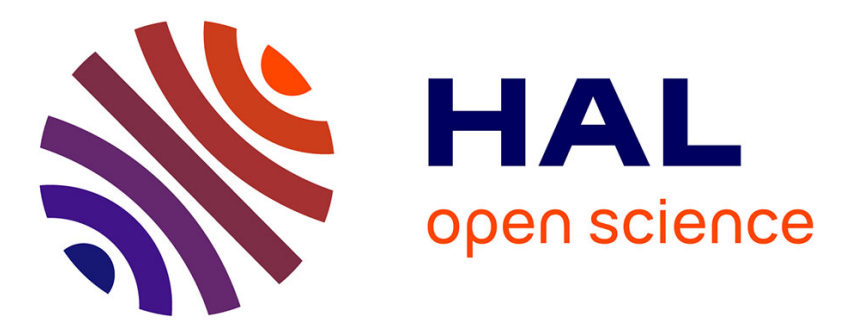

\title{
Shrub biomass estimation in the semiarid Chaco forest: a contribution to the quantification of an underrated carbon stock
}

\author{
Georgina Conti, Lucas Enrico, Fernando Casanoves, Sandra Díaz
}

\section{- To cite this version:}

Georgina Conti, Lucas Enrico, Fernando Casanoves, Sandra Díaz. Shrub biomass estimation in the semiarid Chaco forest: a contribution to the quantification of an underrated carbon stock. Annals of Forest Science, 2013, 70 (5), pp.515-524. 10.1007/s13595-013-0285-9 . hal-01201495

\author{
HAL Id: hal-01201495 \\ https://hal.science/hal-01201495
}

Submitted on 17 Sep 2015

HAL is a multi-disciplinary open access archive for the deposit and dissemination of scientific research documents, whether they are published or not. The documents may come from teaching and research institutions in France or abroad, or from public or private research centers.
L'archive ouverte pluridisciplinaire HAL, est destinée au dépôt et à la diffusion de documents scientifiques de niveau recherche, publiés ou non, émanant des établissements d'enseignement et de recherche français ou étrangers, des laboratoires publics ou privés. 


\title{
Shrub biomass estimation in the semiarid Chaco forest: a contribution to the quantification of an underrated carbon stock
}

\author{
Georgina Conti • Lucas Enrico • Fernando Casanoves • \\ Sandra Díaz
}

Received: 18 November 2012 / Accepted: 1 April 2013 /Published online: 19 April 2013

(C) INRA and Springer-Verlag France 2013

\begin{abstract}
- Context The quantification of biomass of woody plants is at the basis of calculations of forest biomass and carbon stocks. Although there are well-developed allometric models for trees, they do not apply well to shrubs, and shrub-specific allometric models are scarce. There is therefore a need for a standardized methodology to quantify biomass and carbon stocks in open forests and woodlands.

- Aims To develop species-specific biomass estimation models for common shrubs, as well as a multispecies shrub model, for the subtropical semiarid Chaco forest of central Argentina.

- Methods Eight shrub species (Acacia aroma, Acacia gilliesii, Aloysia gratissima, Capparis atamisquea, Celtis ehrenbergiana, Larrea divaricata, Mimozyganthus
\end{abstract}

Handling Editor: Shuqing Zhao

Contribution of the co-authors Georgina Conti conducted sampling design, field work, and data analysis and wrote the manuscript. Lucas Enrico participated in field work and in writing the manuscript. Fernando Casanoves helped in data analysis and manuscript revision. Sandra Díaz coordinated the research project and participated in writing the manuscript.

Electronic supplementary material The online version of this article (doi:10.1007/s13595-013-0285-9) contains supplementary material, which is available to authorized users.

G. Conti $(\bowtie) \cdot$ L. Enrico $\cdot$ S. Díaz

Instituto Multidisciplinario de Biología Vegetal

(IMBIV-CONICET) and Departamento de Diversidad Biológica y

Ecología, FCEFyN, Universidad Nacional de Córdoba, Vélez

Sársfield 1611, CC 495, X5000ZAA, Córdoba, Argentina

e-mail: georconti@gmail.com

F. Casanoves

Biometric Unit, CATIE 7170, Turrialba 30501, Costa Rica carinatus, and Moya spinosa) were selected, and, on average, 30 individuals per species were harvested. Their total individual dry biomass was related with morphometric variables using regression analysis.

- Results Crown area as well as crown-shaped variables proved to be the variables with the best performance for both species-specific and multispecies shrub models. These allometric variables are thus recommended for standardized shrub biomass assessments.

- Conclusion By accounting for the shrub component of the vegetation, our models provide a way to improve the quantification of biomass and carbon in semiarid open forest and woodlands.

Keywords Allometric models · Biomass quantification · Carbon inventories $\cdot$ Chaco $\cdot$ Dimensional relationships . Shrub

\section{Introduction}

Plant biomass is a key ecosystem property resulting from the net balance between carbon gains through photosynthesis and losses by respiration, tissue turnover, and natural or human-induced removal (Chapin et al. 2011). The quantification of forest biomass has a long history because of the importance of its derived products to many societies (e.g., timber, fuel). It has received renewed attention in the past decades because forest standing biomass represents about $44 \%$ of the world forest carbon pool (Pan et al. 2011) and therefore plays a fundamental role in climate change mitigation. The United Nations Framework Convention on Climate Change has included plant biomass as an essential climate variable needed to improve the prediction and 
mitigation of global climate change and its impact on human societies (GTOS 2010). Renewed interest in improving measurement of biomass comes from the Reduction of Emissions due to Deforestation and Forest Degradation mechanisms (REDD and REDD+), which require the monitoring of changes in carbon fluxes and stocks in the context of deforestation and forest degradation.

Plant biomass is often estimated by harvesting a sample of individuals of a species or growth form and relating their dry mass with morphometric variables through an allometric model (usually referred to as a "dimensional analysis" sensu Whittaker and Woodwell 1968). Dimensional analysis to quantify biomass relies on the consistency of an allometric relationship between plant dimensions and the dry mass for a given species or group of species (Jenkins et al. 2004). For tree species, stem-related variables, specifically diameter and height, have proven to accurately predict individual biomass (Chave et al. 2005). The development of general or speciesspecific tree biomass functions, as well as the standardization of their parameters, has experienced a global surge during the last few years as part of the research on climate change (Brown 1997; Chave et al. 2005; Jenkins et al. 2003; Ketterings et al. 2001; Nelson et al. 1999; Pilli et al. 2006).

In woodlands and open forests, woody development takes different physiognomies, with shorter individuals with high basal ramification resulting in a high crown area. The standard diameter at breast height commonly used in forestry studies, is thus impractical in these systems. On the other hand, measuring only the main stem would result in an underestimation of the actual biomass stored in the forest. In multistemmed species estimations, each stem is usually considered as a separated tree, applying the standard relationship between diameter and height with biomass per stem. However, this can be extremely time consuming for shrub species with more than ten ramifications per plant, as is common in the Chaco (Fig. 1). In addition, variables that express the size of the crown often appear to be more useful for shrub biomass estimations, since they define better the architecture of the shrub (Chojnacky and Milton 2008; Hierro et al. 2000; Hofstad 2005; Murray and Jacobson 1982; Oñatibia et al. 2010; Vilà 1993).

Allometric models for open forests and woodlands are much less common than those for closed forests, likely because the former store less carbon per unit area and also because shrublands and the shrub component of forests and woodlands have less economic value (e.g., as timber) and tend to not be represented in forestry inventories. However, shrubs represent a large biomass and carbon pool usually underestimated in carbon storage assessments, a pattern especially true for the subtropical Chaco region, the most extensive semiarid forest in South America (Conti and Díaz 2013).

Biomass models have been developed for a number of shrub species in different ecosystems of the world (Ludwig

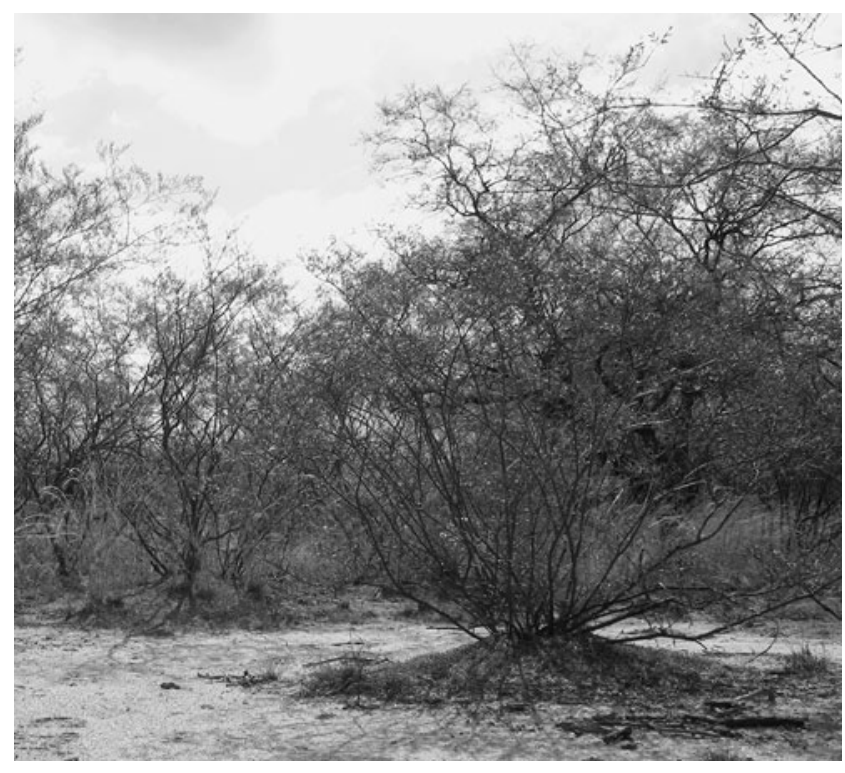

Fig. 1 Larrea divaricata, showing a typical multistemmed architecture in the semiarid Chaco vegetation of central Argentina

et al. 1975; Lufafa et al. 2009; Murray and Jacobson 1982; Sampaio and Silva 2005; Vora 1988; Zeng et al. 2010), but only a few species-specific equations for shrubs from (or common to) the Chaco forest have been published to date (Gaillard de Benitez et al. 2002; Hierro et al. 2000; Iglesias et al. 2012; Iglesias and Barchuk 2010; Northup et al. 2005). In particular, there are several common shrub species in the Chaco ecosystems for which species-specific allometric models have not yet been developed, and there are not generalized multi-species models specifically for shrubs published to date. Iglesias and Barchuk (2010) and Iglesias et al. (2012) proposed some different allometric models for groups of functionally similar shrubs based on stem-related variables (diameter and height).

In this study, we aimed to develop species-specific biomass estimation models for eight common shrubs in the semiarid Chaco forest of central Argentina. We tested the relative performance of crown-related variables over stem-related ones to predict individual shrub aboveground biomass. We also developed a multispecies shrub model for the semiarid Chaco forest. Although this study includes only Chaco shrub species, we provide a basis for the standardization of useful variables to predict more accurately the aboveground shrub biomass component of open forests and woodlands.

\section{Material and methods}

\subsection{Study area}

The study was carried out in central-western Argentina (between $31^{\circ} 16^{\prime}-31^{\circ} 37^{\prime} \mathrm{S}$ and $65^{\circ} 25^{\prime}-65^{\circ} 32^{\prime} \mathrm{W}$ ), covering 
an area of about $450 \mathrm{~km}^{2}$ within the semi-arid southern extreme of the Gran Chaco subtropical seasonal forest (Morello et al. 1977). The climate is monsoon-like with a mean annual precipitation of $550 \mathrm{~mm}$ concentrated to spring-summer (October-March) and a mean annual temperature of $20{ }^{\circ} \mathrm{C}$ (Capitanelli 1979). Soils are mainly sandy-loam aridisols of alluvial origin (Gorgas and Tassile 2003). The dominant vegetation is an open woodland whose canopy is dominated by the trees Aspidosperma quebrachoblanco and Prosopis flexuosa. The dense shrub layer is dominated by several multistemmed species of families such as Fabaceae and Zygophyllaceae, with Mimozyganthus carinatus, Acacia gilliesii, and Larrea divaricata being the most abundant species (Cabido et al. 1992). At present, the Chaco most "pristine" vegetation is represented by very small patches of well-preserved forest embedded in a mosaic of shrub-dominated ecosystem types in different stages of succession, degradation, or management.

\subsection{Species selection}

Following the floristic description of the area by Cabido et al. (1992), as well as our own field surveys, we selected eight subcanopy shrub species including Acacia aroma, A. gilliesii, Aloysia gratissima, Capparis atamisquea, Celtis ehrenbergiana, L. divaricata, M. carinatus, and Moya spinosa. Nomenclature followed Zuloaga and Morrone (1996, 1999) and their regular online updates at http:// www2.darwin.edu.ar/Proyectos/FloraArgentina/FA.asp. In this study, we considered a shrub any individual woody plant with multiple basal stems growing from the same root system (Chojnacky and Milton 2008). In the case of $C$. ehrenbergiana, which includes trees as well as shrubs, we considered only the shrub form (formerly called Celtis pallida); therefore, we did not test the applicability of the equation to the tree form of this species (formerly called Celtis tala). A list of scientific and common names and their synonyms is included in Online Resource 1.

Although all species are common across the study area, some of them are more abundant in closed forest patches, while others appear predominantly associated to open shrublands and degraded sites. Among the selected species, C. atamisquea, C. ehrenbergiana, and $M$. spinosa are closed related to primary forests. Species like A. gilliesii, M. carinatus, and L. divaricata are widely distributed across all vegetation types in the area, but the first two species appeared as dominant in forests and closed shrublands, while $L$. divaricata clearly did so in open shrublands and degraded areas. A. gratissima and C. ehrenbergiana are especially abundant in selectively logged sites. A. aroma is the species with the lowest abundance in the area and seems to be more associated to roadsides and watering holes.

\subsection{Species sampling}

An average of 30 individuals per species were chosen in order to cover the widest possible range of plant sizes observed in the field for each species. The selected species were sampled across the study area keeping climatic and soil conditions as constant as possible. Several variables often used in allometric estimations of shrub biomass were measured in every individual plant prior to destructive sampling: total height ( $H$, centimeters), defined as the distance between the ground surface and the highest crown point; diameter of the longest stem (DLS, centimeters) over the root collar (usually between 5 and $10 \mathrm{~cm}$ from the ground surface); number of ramifications emerging from the root collar $(\mathrm{NR})$; maximum crown diameter $\left(\mathrm{CD}_{1}\right.$, centimeters), and its perpendicular diameter $\left(\mathrm{CD}_{2}\right.$, centimeters). Crown diameters were used to calculate crown area as follows:

$\mathrm{CA}=\pi \times\left(R_{1} \times R_{2}\right)$

where

CA Crown area (square centimeters)

$R_{1} \quad$ Radius from the longest crown diameter $\left(\mathrm{CD}_{1}\right)$ in centimeters

$R_{2} \quad$ Radius from the crown diameter, perpendicular to $\mathrm{CD}_{1}\left(\mathrm{CD}_{2}\right)$ in centimeters

In addition, we tested the performance of two variables related to the crown shape, based on different geometric volumes, with respect to stem variables to predict shrub dry aboveground biomass (Ludwig et al. 1975). Models including crown shape-related variables are expected to be simpler and more accurate alternatives for biomass estimation in the case of shrubs than in the case of trees. We tested an inverted cone-shaped crown $(\mathrm{CoC})$ following the form $\mathrm{CD}^{2} \mathrm{H}$ and a hemisphere-shaped crown $(\mathrm{HsC})$ following the form $\mathrm{CD}^{3}$ as dry biomass predictor variables, using simple linear models. Formulas and calculations are shown in Online Resource 2.

Individual shrubs were cut down at ground level, and the total weight was obtained in the field using a hanging scale (Nops Goldenlark OEM BT-203, accuracy $=0.1 \mathrm{~kg}$ ). Fresh subsamples of wood and twigs with leaves were collected from five individuals per species, stored in sealed plastic bags, and transported to the laboratory where fresh and oven-dried weights (air-forced oven at $80{ }^{\circ} \mathrm{C}$ until constant weight) were obtained to estimate the water content (percent) per species. The resulting value of water content per species was therefore subtracted from the individual fresh mass weighted in the field to obtain the aboveground dry biomass (AGB) per individual per species (Whittaker and Woodwell 1968). This was the final variable used as dependent variable in the regression analysis. 
Wood specific gravity (WSG) is a trait usually included in biomass estimation, with proven predictive value in generalized tree models (Chave et al. 2005). We tested whether the inclusion of this specific trait improved the fitness of a multispecies aboveground biomass regression model. WSG is the oven-dry mass of a woody stem divided by its green volume in kilograms per cubic decimeter. WSG values per species were estimated over six samples collected from the thickest basal stem of six mature individuals in the field using a hatchet. In the lab, each fresh stem sample was totally immersed for $5 \mathrm{~s}$ in a volumetric flask of known weight filled with distilled water, and the increase in weight was recorded. The weight increment equals the green volume of the wood sample. After the volume measurement, the wood sample was oven-dried until it achieved constant weight. Wood specific density was then calculated as the oven-dry mass of the wood sample divided by the mass of water displaced by its green volume (Pérez Harguindeguy et al. 2013).

\subsection{Statistical analysis}

Species-specific regression analyses were performed between dry biomass and allometric variables, and their relative performances were compared. In addition, we constructed a set of multispecies aboveground biomass regression models considering all individuals from the eight shrubs species together ( $n$ $=245$ ). These models also estimated the individual shrub aboveground dry biomass without considering the species sampled. If necessary, variables were log-transformed in order to apply linear models. Three different allometric models were developed: (1) single-variable model refers to the model including the best fitted variable, (2) multiple-variables model refers to the best multiple model selected after include all variables, and (3) crown model refers to the model including only variables related to the crown shape. Single-variable and crown models were obtained using simple linear regression models. Multiple-variables models were obtained using multiple linear regression models.

The best statistical model developed for either individual species or all species considered together was selected according to the Akaike Information Criterion (AIC), a likelihood criterion that penalizes the number of parameters (Burnham and Anderson 2002; Johnson and Omland 2004), where the best statistical model has the lowest value of AIC. We also reported the predictive mean squared error of the regression as an alternative statistic reflecting the accuracy of the estimator. Although models including all variables are expected to have a better fit than simpler models, a greater number of predictor variables increases the model complexity and the sources of uncertainty, and thus decreases the precision of the resulting predictions. The principle of parsimony stipulates that the "best" regression model is the model that explains the largest amount of response variability with the fewest predictor terms (Logan 2010). We followed this criterion to select the best regression models used for inference. All statistical analyses were carried out with the statistic software InfoStat v. 2011 (Di Rienzo et al. 2011).

Together with the statistical parameters of log-transformed models, a correction factor (CF) was presented for the bias entailed for the log transformation of the data in the final biomass estimation (Baskerville 1972). Estimations of biomass on the basis of log-transformed variables are expected to underestimate the real value. We thus calculated a $\mathrm{CF}$ to be applied to AGB in those cases where log-transformed variables intervened in the equation. The CF must to be applied to biomass estimation as follows:

$\mathrm{AGB}=\mathrm{CF} \times \mathrm{e}^{\ln (\mathrm{AGB})}$

where,

$\mathrm{CF}=\mathrm{e}^{\left(\frac{\mathrm{SEE}^{2}}{2}\right)}$

CF Correction factor

SEE Standard error of the estimation.

\section{Results}

Among the species considered, A. gilliesii showed the highest weights while $A$. gratissima and $C$. ehrenbergiana were the smallest in terms of total aboveground dry biomass and height per individual. M. carinatus and L. divaricata were the tallest and most branched species, with individuals taller than $400 \mathrm{~cm}$ and with more than 20 ramifications. However, they showed intermediate individual aboveground dry biomass. In contrast, A. aroma presented lower height and fewer ramifications than these species, but the highest crown area. Finally, C. atamisquea and M. spinosa had intermediate height, number of ramifications and weight (see Table 1 for the ranges of values of biometric variables and aboveground dry biomass observed per species and for the complete dataset).

\subsection{Species-specific aboveground dry biomass regression} models

The best-fitted models developed per species, corresponding parameters, correction factors, and statistical descriptors are presented in Table 2. Among the single-variable models, CA was the best predictor variable of aboveground dry biomass for all except one species, accounting at least for $50 \%$ of the variability in all cases. The best fit corresponded to $A$. gratissima $\left(R^{2}=0.90, p<0.0001\right)$. The exception was $C$. atamisquea, where DLS instead of CA was the variable that 


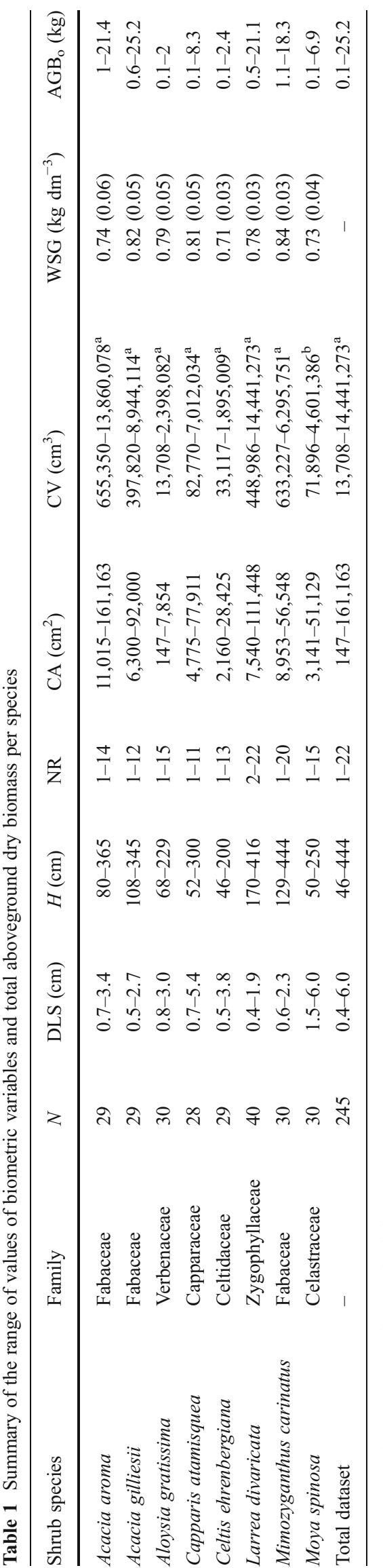

best explained aboveground dry biomass $\left(R^{2}=0.85\right.$, $p<0.0001)$, although CA also performed well $\left(R^{2}=0.82\right.$, $p<0.0001)$. After CA, DLS was the second best predictor variable for species-specific biomass in almost all cases. $\mathrm{H}$ showed intermediate predictive capability, with the highest value for $C$. atamisquea $\left(R^{2}=0.79, p<0.0001\right)$. NR showed the lowest predictive capacity in all cases, with the highest regression coefficient for $A$. gilliesii $\left(R^{2}=0.34, p=0.0009\right)$.

In terms of multiple-variables models, those developed for $C$. atamisquea and A. gratissima had the best predictive capacity $\left(R^{2}=0.96\right.$ and $R^{2}=0.94$ at $p<0.0001$, respectively).

As for crown models, the conical crown model $(\mathrm{CoC})$ was the best predictor of AGB, except in the case $M$. spinosa for which the hemispherical crown model (HsC) showed a better fit (Table 2).

\subsection{Multispecies aboveground dry biomass regression models}

Simple- and multiple-variables models for all species considered together $(n=245)$, their fitted parameters, and statistical descriptors are shown in Table 3. Similar to the speciesspecific models, CA was the variable that best predicted AGB for the complete dataset, followed by height (Fig. 2a, b). The regression between DLS and AGB clearly showed the existence of two groups of species with different dimensional relationships (Fig. 2c). A. aroma, A. gilliesii, L. divaricata, and $M$. carinatus showed more biomass at a given DLS than did A. gratissima, C. atamisquea, $C$. ehrenbergiana, and $M$. spinosa. This could be indicating two different branching patterns; therefore, DLS cannot be considered as a good predictor variable in the generalized multispecies shrub model, at least for systems including these species. NR showed poor predictive capacity and its inclusion in the multiple-variables model did not improved the fit of the model (Fig. 2d).

$\mathrm{H}$ and $\mathrm{CA}$ were the only variables included in the multiple-variables model. As expected, the inclusion of WSG improved the fit of the models. The best crown volume model was the conical one (model V, Table 3), explaining $85 \%$ of aboveground dry biomass variation in the dataset.

Figure 3 shows the performance of the best fitted multispecies model (model IV, Table 3) including $\mathrm{H}$, CA, and WSG. In any case, it is important to note that regression models should not be used beyond their range of validity. Models proposed here are valid between the ranges of allometric variables shown in Table 1, stressing that in the models DLS and $\mathrm{H}$ should be measured in centimeters, $\mathrm{CA}$ in square centimeter, $\mathrm{CoC}$ and $\mathrm{HsC}$ in cubic centimeters, and WSG in kilograms per cubic decimeter. 


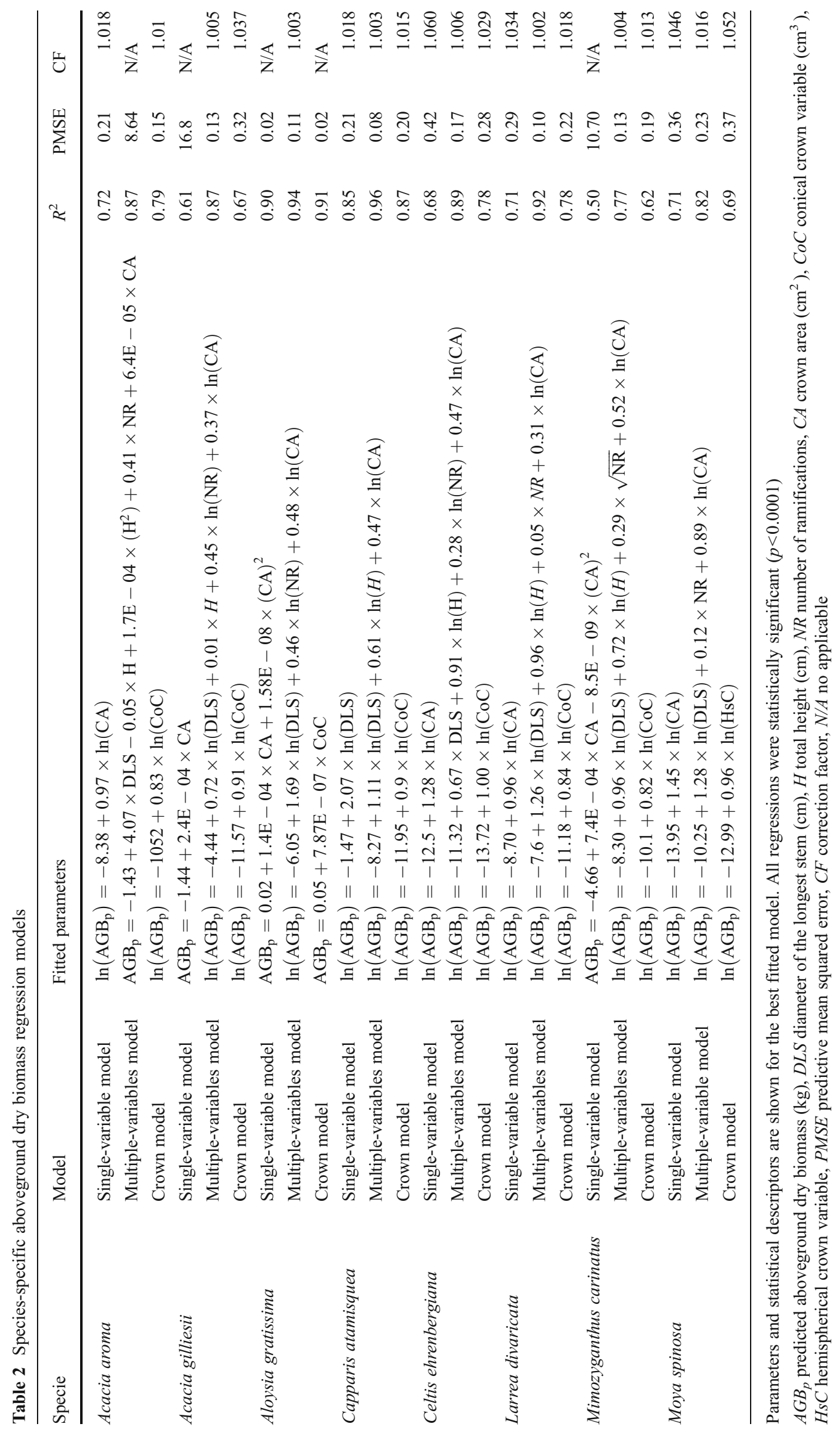


Table 3 Multispecies aboveground dry biomass regression models

\begin{tabular}{|c|c|c|c|c|c|}
\hline Model & Parameters & $R^{2}$ & PMSE & AIC & $\mathrm{CF}$ \\
\hline I. Single- variable model & $\ln \left(\mathrm{AGB}_{\mathrm{p}}\right)=-9.58+1.06 \times \ln (\mathrm{CA})$ & 0.76 & 0.57 & 561.44 & 1.176 \\
\hline $\begin{array}{l}\text { II. Single-variable model } \\
\text { including WSG }\end{array}$ & $\ln \left(\mathrm{AGB}_{\mathrm{p}}\right)=-16.15+1.02 \times \ln (\mathrm{CA})+8.83 \times \mathrm{WSG}$ & 0.81 & 0.43 & 494.50 & 1.097 \\
\hline III. Multiple-variable model & $\ln \left(\mathrm{AGB}_{\mathrm{p}}\right)=-13.79+1.44 \times \ln (H)+0.71 \times \ln (\mathrm{CA})$ & 0.86 & 0.34 & 433.24 & 1.060 \\
\hline $\begin{array}{l}\text { IV. Multiple-variable model } \\
\text { including WSG }\end{array}$ & $\ln \left(\mathrm{AGB}_{\mathrm{p}}\right)=-17.55+1.22 \times \ln (H)+0.75 \times \ln (\mathrm{CA})+5.92 \times \mathrm{WSG}$ & 0.88 & 0.28 & 389.41 & 1.040 \\
\hline V. Crown model & $\ln \left(\mathrm{AGB}_{\mathrm{p}}\right)=-14.14+1.06 \times \ln (\mathrm{CoC})$ & 0.85 & 0.35 & 439.60 & 1.063 \\
\hline $\begin{array}{l}\text { VI. Crown model including } \\
\text { WSG }\end{array}$ & $\ln \left(\mathrm{AGB}_{\mathrm{p}}\right)=-17.33+1.02 \times \ln (\mathrm{CoC})+4.82 \times \mathrm{WSG}$ & 0.86 & 0.31 & 416.89 & 1.049 \\
\hline
\end{tabular}

Parameters and statistical descriptors are shown for the best fitted model. All regression analyses were statistically significant $(p<0.0001)$

$A G B_{p}$ predicted aboveground dry biomass $(\mathrm{kg}), H$ total height $(\mathrm{cm}), C A$ crown area $\left(\mathrm{cm}^{2}\right), W S G$ wood specific gravity $\left(\mathrm{kg}\right.$ dm $\left.{ }^{-3}\right), C o C$ Cone shaped crown variable $\left(\mathrm{cm}^{3}\right), H s C$ hemisphere-shaped crown variable, $R^{2}$ regression coefficient, $P M S E$ predictive mean squared error, $A I C$ Akaike information criterion, $C F$ correction factor, $N / A$ no applicable

\section{Discussion}

Biomass allometric models specifically developed for shrubs are scarce in the literature. This article makes a contribution in that sense by testing the validity of several equations and variables, including crown-related variables, for the prediction of individual shrub aboveground dry biomass in the semiarid Chaco forest of central Argentina.

Although the results presented in this study showed that the multiple-variables models performed better than singlevariable and crown models, the later ones seem to have more applicability since were more parsimonious while still retaining good predictive capability. In practice, dealing with several variables could be very laborious and attention has to be paid to the range of validity of each variable separately, so models including fewer variables are convenient and therefore preferred.

Since crown models had an intermediate fit between multiple- and single-variable models and include just two allometric variables combined ( $\mathrm{H}$ and $\mathrm{CA}$ ) in a single variable, we recommend using those models to predict aboveground dry biomass of shrub species. The final selection criterion
Fig. 2 Relationship between the aboveground dry biomass $(\mathrm{kg})$ and a crown area $\left(C A, \mathrm{~cm}^{2}\right), \mathbf{b}$ height $(H, \mathrm{~cm})$, c diameter of the longest stem $(D L S, \mathrm{~cm})$, and $\mathbf{d}$ number of ramifications for the complete dataset. Different symbols and colours represent different species. Only CA and $H$ were useful variables to predict multispecies aboveground shrub biomass

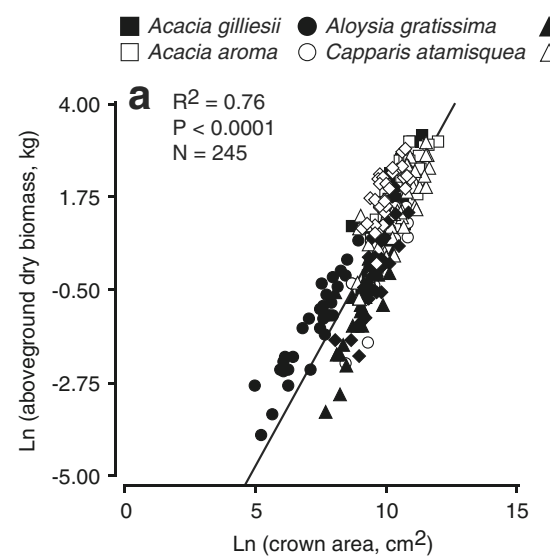

Celtis ehrenbergiana Moya spinosa Larrea divaricata $\diamond$ Mimozyganthus carinatus
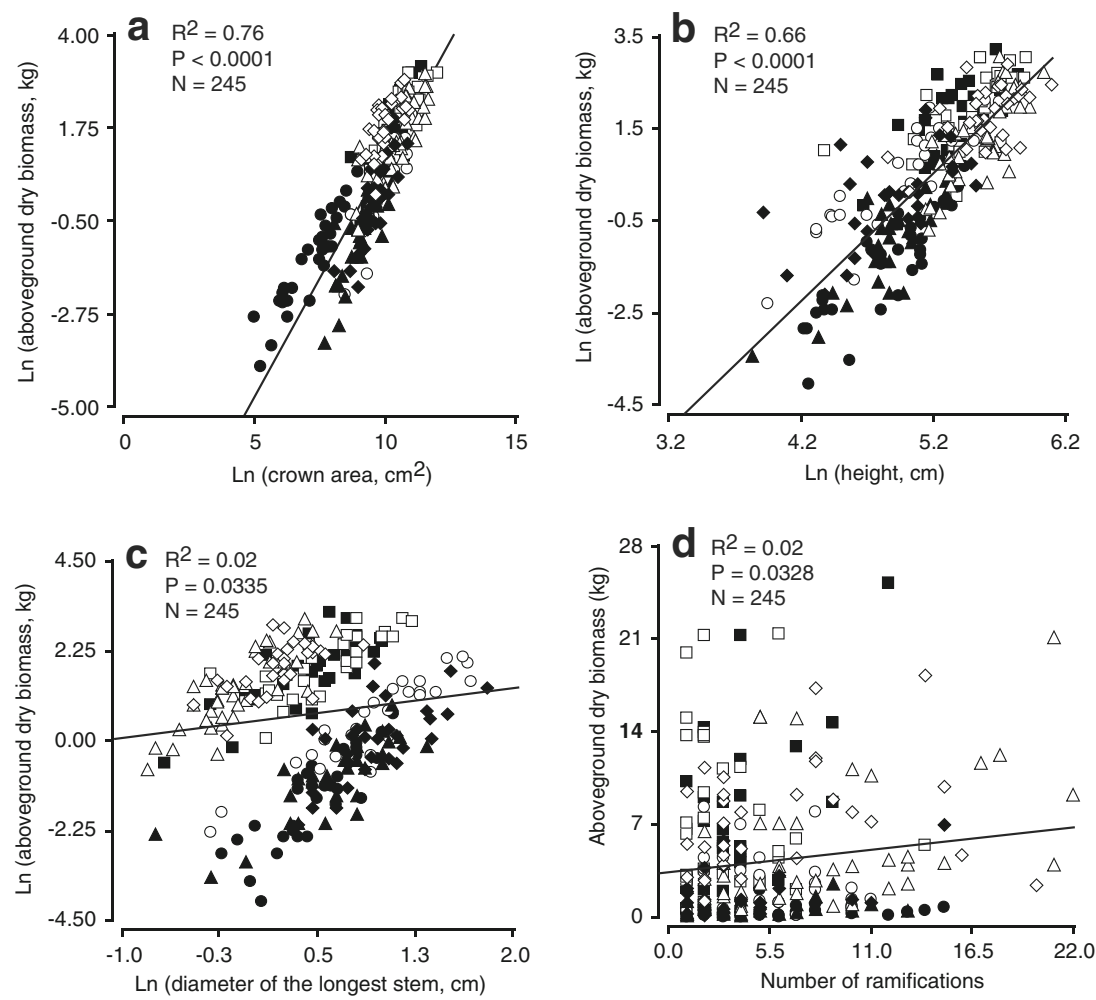


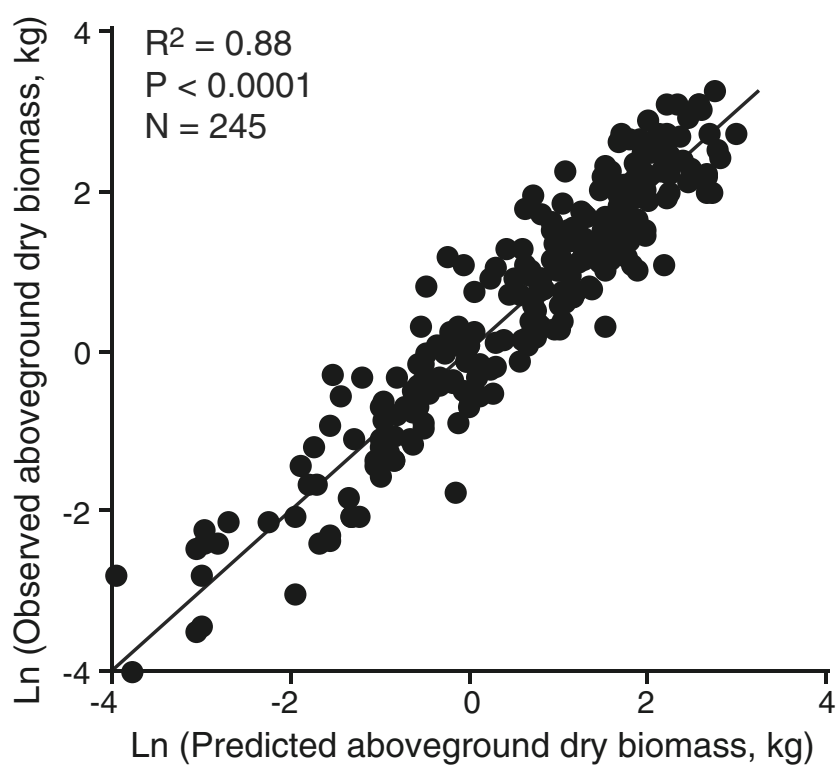

Fig. 3 Capacity of model IV for predicting shrub aboveground biomass, considering all species together. Each dot corresponds to an individual weighted shrub $\ln \left(\mathrm{AGB}_{\mathrm{p}}\right)=-17.55+1.22 \times \ln (H)+$ $0.75 \times \ln (\mathrm{CA}+5.92 \times \mathrm{WSG}$

between the presented models will depend on the data available for the biomass estimation as well as on the aim of the research project at hand.

After developing 24 species-specific equations for eight shrub species, we strongly recommend the use of crownand height- related variables over other common allometric variables as predictors of individual aboveground biomass of shrubs in semiarid Chaco forests and woodlands. Among the allometric variables sampled, we found that crownrelated variables were the best predictors of shrub biomass in both species-specific and multispecies models, which is in agreement with the size-biomass relationship found for shrubs in other semiarid ecosystems (Ludwig et al. 1975; Murray and Jacobson 1982; Northup et al. 2005). Several other studies that applied crown-volume equations to the estimation of individual shrub biomass in different ecosystems or vegetation types, such as Mediterranean shrublands (Castro and Freitas 2009; Paton et al. 2002), the Chihuahan desert (Ludwig et al. 1975), the Monte desert in western Argentina (Hierro et al. 2000), and the shrub component of pine forests from subtropical China and southern USA (Sah et al. 2004; Zeng et al. 2010) have also obtained good fits. The fact that shrub aboveground biomass could be accurate predicted using a single variable of crown area across different ecosystems regardless of species identity makes an important contribution in the improvement of global biomass estimates, since it provides a very powerful tool to estimate shrub aboveground biomass from remote sensing data (Phua and Saito 2003). Our results also confirmed that the use of natural $\log -\log$ models is the most appropriate form for providing a common statistical basis for describing size-biomass relationships in almost all cases presented, as was found for others shrub species around the world (Hierro et al. 2000; Hofstad 2005; Oñatibia et al. 2010; Sah et al. 2004; Smith and Brand 1983; Tietema 1993).

Diameter of the longest stem, which was a good predictor for species-specific models, as found by Hierro et al. (2000), is not recommended for multispecies models because species in this region seem to belong to different groups characterized by different branching patterns. Height appeared as a more relevant variable in the case of multispecies models than for species-specific models. Unlike trees, the estimation of shrub height is very simple and can be made using a simple tape. Finally, the number of ramifications showed very little predictive value and it is very laborious to measure at field, particularly in thorny multistemmed shrubs, such as some of the species measured in this study. Our results differ from those by Vilà (1993) for Mediterranean resprouting shrub species, where the variable "number of branches" significantly improved the fit of the allometric biomass models.

Iglesias and Barchuk (2010) and Iglesias et al. (2012) presented equations for different groups of Chaco shrubs: $A$. gilliesii and $M$. carinatus separately and together; $L$. divaricata, as well as different equations for two groups of shrubs species including A. grattissima, C. ehrenbergiana, and Lycium ciliatum on the one side and C. atamisquea and Condalia microphylla on the other. Although useful, these equations are only applicable for individuals having a lower number of ramifications since the authors only include basal stem diameter and height considering each of the basal stems of a shrub as a separate individual. The stem diameter, easily obtainable in the case of trees, can be particularly time consuming to obtain in shrub species commonly having more than 10 (and sometimes up to 20) ramifications per plant. In comparison, measuring crown diameters and height of shrubs is considerably quicker, easier, and more accurate (Northup et al. 2005). Gaillard de Benitez et al. (2002) obtained very precisely estimations of the biomass of $L$. divaricata using an equation with the predictive variables basal perimeter, crown perimeter, ramification number, and crown volume (but not crown area). However, the best predictor variable found in that study, crown perimeter, is notoriously time consuming and difficult to measure in the field, as pointed out by the same authors. Our work, on the other hand, set out to find accurate yet simple estimations of several shrub species individually and together without the need to measure different predictor variables for different shrubs species, or to include difficult or time-consuming variables.

Hierro et al. (2000) developed biomass equations for $L$. divaricata in the Monte shrublands, using an inverted cone volume as the best predictor variable, similar to those reported in our study. The parameters finally included in 
both equations of Hierro et al. and ours are quite similar, suggesting that the individuals in the Monte ecosystems are equivalent in terms of size and architecture to the individuals sampled in the Chaco region for this particular species. The same pattern applied to the comparison with the total aboveground dry biomass model for $C$. ehrenbergiana (formerly called $C$. pallida) developed in the subtropical thornscrub parklands of southern Texas and using crown area as a predictor variable (Northup et al. 2005).

Different multispecies models for the estimation of aboveground dry biomass showed similar predictive capacity with no relevant difference in the number of variables included (e.g., multiple-variable models included the same variables needed to estimate the conical crown models). Based on the AIC, the best predictive model founded in the present work was the one that included $H, \mathrm{CA}$, and WSG (model IV in Table 3). Even when WSG - a trait commonly measured and reported in the forestry literature-improved the fit of the models, differences in their predictive capability were not large enough to justify measuring WSG, since it involves the additional time-consuming activities of extracting the samples, processing, and measuring them in the laboratory. Accordingly, we recommend model III because of its good balance between number of input variables needed and predictive capacity. However, and for practical purposes, model I including just crown area as a predictive variable offer an accurate, practical, fast, and inexpensive way to estimate shrub aboveground biomass in open forest ecosystems. Crown area is a variable easily obtained using fine spatialresolution data (i.e., aerial photographs,) allowing an indirect estimation of individual shrub aboveground biomass.

All models included in Table 3 should perform well in predicting shrub aboveground biomass in semiarid Chaco forests. The decision about the best predictive model to use for the biomass estimation is thus to be made on the basis of the available variables.

Although species-specific equations often provide more accurate estimates of biomass than multispecies aboveground biomass regression models, as was found in this study, generalized (multispecies) regression models could provide useful estimations in similar woody open ecosystems where species-specific equations are not yet available and the proposed variables could be correctly measured. Furthermore, it is preferable to use region or site-specific relationships whenever possible, since species size-biomass relationship could differ as plants alter allocation patterns in response to soils, climate and disturbance (Northup et al. 2005).

The models provided here should contribute to the inclusion of shrubs in open woodland and forest biomass estimations to biological carbon stocks as well as providing tools for a methodological standardization for the quantification of individual dry biomass in shrub species.
Acknowledgments We are grateful to C. Rodriguez, G. Bertone, P. Jaureguiberry, and $\mathrm{M}$. Bonino for their valuable field assistance during the development of this work.

Funding This study was funded by FONCyT, CONICET, Universidad Nacional de Córdoba, and the DiverSus programme through InterAmerican Institute for Global Change Research (IAI) CRN 2015 and SGP-CRA2015, which were supported by the US National Science Foundation grants GEO-0452325 and GEO-1138881. GC and LE student grants are from CONICET and Fundación Bunge y Born.

\section{References}

Baskerville GL (1972) Use of logarithmic regression in the estimation of plant biomass. Can J For Res 2:49-53. doi:10.1139/x72-009

Brown S (1997) Estimating biomass and biomass change of tropical forests: a primer, vol 134. FAO Forestry Paper. A forest resource assessment publication. FAO, Rome

Burnham KP, Anderson DR (2002) Model selection and inference. A practical information-theoretic approach, 2nd edn. Springer, Berlin-Heidelberg-New York

Cabido M, Acosta A, Carranza ML, Diaz S (1992) La vegetación del Chaco Árido en el W de la provincia de Córdoba, Argentina. Doc Phytosociol XIV:447-456

Capitanelli R (1979) Clima. In: Vázquez J, Miatello R, Roque M (eds) Geografía física de la provincia de Córdoba. Ed. Boldt, Buenos Aires, pp 45-138

Castro H, Freitas H (2009) Above-ground biomass and productivity in the Montado: from herbaceous to shrub dominated communities. J Arid Environ 73:506-511. doi:10.1016/j.jaridenv.2008.12.009

Chapin FS III, Matson PA, Vitousek PM (2011) Principles of terrestrial ecosystem ecology, 2nd edn. Springer, New York

Chave J, Andalo C, Brown S, Cairns MA, Chambers JQ, Eamus D, Fölster H, Fromard F, Higuchi N, Kira T, Lescure J-P, Nelson BW, Ogawa H, Puig H, Riéra B, Yamakura T (2005) Tree allometry and improved estimation of carbon stocks and balance in tropical forests. Oecologia 145:87-99. doi:10.1007/s00442-005-0100-x

Chojnacky DC, Milton M (2008) Measuring carbon in shrubs. In: Hoover $\mathrm{CM}$ (ed) Field measurements for forest carbon monitoring. Springer, New York, pp 45-72

Conti G, Díaz S (2013) Plant functional diversity and carbon storage - an empirical test in semi-arid forest ecosystems. J Ecol 101:18-28. doi:10.1111/1365-2745.12012

Di Rienzo JA, Casanoves F, Balzarini MG, Gonzalez L, Tablada M, Robledo CW (2011) InfoStat. Statistical software. Grupo Infostat FCA UNC, Córdoba

Gaillard de Benitez C, Pece M, Juárez de Galíndez M, Vélez S, Gómez A, Zárate M (2002) Determinación de funciones para la estimación de biomasa aérea individual de jarilla (Larrea divaricata) de la provincia de Santiago del Estero, Argentina. For Ver 4:23-28

Gorgas J, Tassile J (2003) Recursos naturales de la provincia de Córdoba. Los suelos. Agencia Córdoba Ambiente S.E. - INTA EEA Manfredi, Córdoba

GTOS (2010) A framework for terrestrial climate-related observations and development of standards for the terrestrial essential climate variables: proposed workplan. FAO, ICSU, UNEP, UNESCO, WMO. http://www.fao.org/gtos/doc/pub78.pdf. Accessed 13 Nov 2012

Hierro JL, Branch LC, Villarreal D, Clark KL (2000) Predictive equations for biomass and fuel characteristics of Argentine shrubs. J Range Manage 53:617-621. doi:10.2307/4003156

Hofstad O (2005) Review of biomass and volume functions for individual trees and shrubs in southeast Africa. J Trop For Sci 17: $151-162$ 
Iglesias MR, Barchuk AH (2010) Estimación de la biomasa aérea de seis leguminosas leñosas del Chaco Árido (Argentina). Ecol Austral 20:71-79

Iglesias MR, Barchuk A, Grilli MP (2012) Carbon storage, community structure and canopy cover: a comparison along a precipitation gradient. For Ecol Manage 265:218-229. doi:10.1016/j.foreco. 2011.10.036

Jenkins JC, Chojnacky DC, Heath LS, Birdsey RA (2003) National-scale biomass estimators for United States tree species. For Sci 49:12-35

Jenkins JC, Chojnacky DC, Heath LS, Birdsey RA (2004) Comprehensive database of diameter-based biomass regressions for North American tree species. US Department of Agriculture, Forest Service, Northeastern Research Station, Delaware

Johnson JB, Omland KS (2004) Model selection in ecology and evolution. Trends Ecol Evol 19:101-108. doi:10.1016/j.tree.2003.10.013

Ketterings QM, Coe R, van Noordwijk M, Ambagau Y, Palm CA (2001) Reducing uncertainty in the use of allometric biomass equations for predicting above-ground tree biomass in mixed secondary forests. For Ecol Manage 146:199-209. doi:10.1016/ s0378-1127(00)00460-6

Logan M (2010) Biostatistical design and analysis using R. A practical guide. Wiley-Blackwell, UK

Ludwig JA, Reynolds JF, Whitson PD (1975) Size-biomass relationships of several Chihuahuan desert shrubs. Am Midl Nat 94:451461. doi: $10.2307 / 2424437$

Lufafa A, Diédhiou I, Ndiaye NAS, Séné M, Kizito F, Dick RP, Noller JS (2009) Allometric relationships and peak-season community biomass stocks of native shrubs in Senegal's Peanut Basin. J Arid Environ 73:260-266. doi:10.1016/j.jaridenv.2008.09.020

Morello JH, Sancholuz LA, Blanco CA (1977) Estudio macroecológico de los Llanos de la Rioja. IDIA 34:242-248

Murray RB, Jacobson MQ (1982) An evaluation of dimension analysis for predicting shrub biomass. J Range Manage 35:451-454. doi: $10.2307 / 3898603$

Nelson BW, Mesquita R, Pereira JLG, Aquino G, de Souza S, Teixeira Batista G, Bovino Couto L (1999) Allometric regressions for improved estimate of secondary forest biomass in the central Amazon. For Ecol Manage 117:149-167. doi:10.1016/s0378-1127(98)00475-7

Northup BK, Zitzer SF, Archer S, McMurtry CR, Boutton TW (2005) Above-ground biomass and carbon and nitrogen content of woody species in a subtropical thornscrub parkland. J Arid Environ 62:23-43. doi:10.1016/j.jaridenv.2004.09.019

Oñatibia GR, Aguiar MR, Cipriotti PA, Troiano F (2010) Individual plant and population biomass of dominant shrubs in Patagonian grazed fields. Ecol Austral 20:269-279

Pan Y, Birdsey RA, Fang J, Houghton R, Kauppi PE, Kurz WA, Phillips OL, Shvidenko A, Lewis SL, Canadell JG, Ciais P, Jackson RB, Pacala SW, McGuire AD, Piao S, Rautiainen A, Sitch S, Hayes D (2011) A large and persistent carbon sink in the world's forests. Science 333:988-993. doi:10.1126/science.1201609
Paton D, Nuñez J, Bao D, Muñoz A (2002) Forage biomass of 22 shrub species from Monfragüe Natural Park (SW Spain) assessed by log-log regression models. J Arid Environ 52:223-231. doi:10.1006/jare.2001.0993

Pérez Harguindeguy N, Díaz S, Garnier E, Lavorel S, Poorter H, Jaureguiberry P, Bret-Harte MS, Cornwell WK, Craine JM, Gurvich DE, Urcelay C, Veneklaas EJ, Reich PB, Poorter L, Wright IJ, Ray P, Enrico L, Pausas JG, De Vos A, Buchmann N, Funes G, Quetier F, Hodgson JG, Thompson K, Morgan HD, Ter Steege H, Van Der Heijden MGA, Blonder B, Poschlod P, Vaieretti MV, Conti G, Staver MC, Aquino S, Cornelissen JHC (2013) New handbook for standardised measurement of plant functional traits worldwide. Aust J Bot. doi:10.1071/BT12225

Phua M-H, Saito H (2003) Estimation of biomass of a mountainous tropical forest using Landsat TM data. Can J Remote Sens 29:429-440. doi:10.5589/m03-005

Pilli R, Anfodillo T, Carrer M (2006) Towards a functional and simplified allometry for estimating forest biomass. For Ecol Manage 237:583-593. doi:10.1016/j.foreco.2006.10.004

Sah JP, Ross MS, Koptur S, Snyder JR (2004) Estimating aboveground biomass of broadleaved woody plants in the understory of Florida Keys pine forests. For Ecol Manage 203:319-329. doi:10.1016/ j.foreco.2004.07.059

Sampaio EVSB, Silva GC (2005) Biomass equations for Brazilian semiarid caatinga plants. Acta Bot Bras 19:935-943

Smith WB, Brand GJ (1983) Allometric biomass equations for 98 species of herbs, shrubs and small trees. US Department of Agriculture, Forest Service, North Central Forest Experiment Station, St. Paul

Tietema T (1993) Possibilities for the management of indigenous woodlands in Southern Africa: a case study from Botswana. In: Pierce GD, Gumbo DJ (eds) The Ecology and management of indigenous forest in Southern Africa. Zimbabwe Forest Commission \& SAREC, Harare, pp 134-142

Vilà M (1993) The use of dimensional analysis to estimate plant resprout biomass. Sci Gerundensis Univ Gerona 19:47-51

Vora RS (1988) Predicting biomass of five shrub species in northeastern California. J Range Manage 41:63-65. doi:10.2307/3898792

Whittaker RH, Woodwell GM (1968) Dimension and production relations of trees and shrubs in the Brookhaven forest, New York. J Ecol 56:1-25. doi:10.2307/2258063

Zeng H-Q, Liu Q-J, Feng Z-W, Ma Z-Q (2010) Biomass equations for four shrub species in subtropical China. J For Res 15:83-90. doi:10.1007/s10310-009-0150-8

Zuloaga FO, Morrone O (1996) Catálogo de las Plantas Vasculares de la República Argentina I, vol 60. Monographs in systematic botany. Missouri Botanical Garden, Missouri

Zuloaga FO, Morrone O (1999) Catálogo de las Plantas Vasculares de la República Argentina II, vol 74. Monographs in systematic botany. Missouri Botanical Garden, Missouri 